\title{
An Analysis of the Locus of Control of the Public Administrators in Gomal University Dera Ismail Khan Khyber Pakhtunkhwa, Pakistan
}

\author{
${ }^{1}$ Dr. Ghulam Muhammad Kundi, ${ }^{1}$ Muhammad Saqib Khan, ${ }^{1}$ Qamar \\ Affaq Qureshi \\ ${ }^{2}$ Robina Akhtar, ${ }^{1}$ Irfanullah Khan \\ ${ }^{1}$ Department of Public Administration, Gomal University, Dera Ismail Khan \\ Khyber Pakhtunkhwa, Pakistan \\ ${ }^{2}$ M.Phil Education, IER, Gomal University, Dera Ismail Khan \\ Khyber Pakhtunkhwa, Pakistan
}

DOI: $\quad 10.6007 /$ IJARBSS/v4-i2/665 URL: http://dx.doi.org/10.6007/IJARBSS/v4-i2/665

\begin{abstract}
Locus of control because of its importance as your locus of control says a lot about how you view the world and your role in determining the course of your life. Present study investigates the relationship among demographic groups and research variables. The literature does provide support for the relevant relationship among these variables; however, such evidence is not entirely unambiguous and, therefore, deserving of future study. The sample for the present study comprised of 30 MPA students; 16 males and 14 females. Statistical treatment of the data obtained for the research was done using t-test. Result showed that there is no significant difference between the variables and demographic groups (gender/domicile). Only one variable 'Influence' was found to have significant difference with gender. The study points that why and how influence effects the people's perceptions and how to direct that stream in a positive direction.
\end{abstract}

\section{INTRODUCTION}

As the environment is dynamic and ever changing, we can either attribute success or failure to things we have control over, or to forces outside our influence. Which orientation we choose has a bearing on our long-term success. This orientation is known as our "locus of control". One's "locus" (Latin for "place" or "location") can either be internal, implies the person believes that they control their life, or external in other case, they believe that their environment, some higher power, or other people control their decisions and their life (Babladelis, 1984: 198). Where the construct control means having power over events, strategies or circumstances, including the dimensions of interpersonal control (Chung \& Reigeluth, 1992).

Locus of control evolved from Julian Rotter's (1954) social learning theory of personality. It is related to learned behavior and the reinforcement of such behavior (Rotter, 1966). Bell \& Staw (1989: 365-378) considered the locus of control to be a dispositional trait. The construct refers to the extent of the belief of a person in terms of whether or not the individual believes that actions taken can affect outcomes. If someone feels that he is in control of what happens, then 
he has an internal locus of control (Phillips \& Bedeian, 1994). Persons with a high degree of internal control are more confident and assertive, and active searchers for information that will help them to achieve their own objectives, and are attracted to situations that offer opportunities of achievement (Barbara, 1985) 420; Bush, 1988). In contrast, if someone feels that fate, luck, or chance affects what happens to him then he has an external locus of control. Externally controlled persons see that reinforcement does not come from their own behaviors but from events that are beyond their capacity (Nielson, 1982: 266).

Locus of control in social psychology refers to the extent to which individuals believe that they can control events that affect them. Its study dates back to the 1966, with Julian Rotter's investigation into how people's behaviors and attitudes affected the outcomes of their lives. His concept has two dimensions, at one extreme, according to him are the people who believe that they are autonomous and they themselves are masters of their own fate and bear personal responsibility for what happens to them. They see the control of their lives as coming from inside themselves; such people are called by him as "Internalizers". Likewise, on other continuum, Rotter also hold that many people view themselves as helpless pawns of fate, controlled by outside forces over which they have little influence, and these people believe that the locus of control is external rather than internal, Rotter call them as "Externalizers".

Barbara (1985), while working on the Rotter's concept explored that; an important construct in Rotter's personality theory is that of internal versus external control of reinforcement. In which we can see how an individual's expectancies concerning the effect of his or her behavior influence his or her actions (Phillip, 1985). Rotter believes that these expectancies can generalize to high freedom of movement for a larger variety of reinforcement and even to reinforcement in general. Thus, an individual may come to believe on the basis of his past experiences that the reinforcement that he receives depend on his own behaviors or, conversely, may come to believe that reinforcement are controlled by outside forces.

Succinctly, locus of control, has, in fact, been one of the most widely researched personality variables. The relation between student's achievement and locus of control has also been much studied. Findings by Phares (1976: 222), Frierei (1980), and Nelson (1982) suggest that locus of control may be the single most important personality attribute associated with underachievement. Underachievers and school dropouts have, for instance, been found to score as externals on measures of locus of control (Fuhrmann, 1986). In a study with 54 students with average age of 26 years, Lester (1992) found a stronger belief in an internal locus of control associated with greater competitiveness, while a stronger belief in external control by chance associated with a greater desire to avoid success (Richard et al., 2006: 47).

The Department of Public Administration Gomal University DIKhan has been working since the establishment of Gomal University in 1974 entrusted with the responsibility to produce high quality competent professionals to run the governmental affairs in most effective, efficient and responsible way. The students enrolled in different programs come from diverse background and cultures across Pakistan. They spent two years in the class-room teaching besides two months intensive internship training; they conduct and publish a research paper on topic of their choice to get command on scientific decision making. Some of the students are intro-ward while, others are extro-ward, their attitude, behavior, and way of thinking and doing work is altogether different. Whereas locus of control is their personality construct, which is referred to 
their individual's perception of the locus of events as determined internally by their own behavior vs. fate, luck, or external circumstances.

This study is of an equal importance for the students of Masters of public administration which will help them to understand the way they perceive different aspects of their academic life. It will be also helpful to give the students an insight into locus of control as a psychological construct to enhance their vision. Moreover, this research will provide useful guidance for the future researchers.

The purpose of this study was to understand, examine and interpret the views of students about the factors affecting their locus of control in order to highlight the impact of influence, experience, belief, and ability upon the respondents, and finally to offer way-out for changing locus of control.

\section{PROBLEM STATEMENT}

This academic research is basically aimed at measuring the perceptions of students towards Locus of control in connection with belief, experience, influence and ability. This study will also highlight the importance of each variable and its role in the personality development of the future administrators of the country by drawing inference and offer recommendations based on the empirical evidence.

\section{HYPOTHSIS}

Sekaran (2004: 103) is of the view that a hypothesis as a logically conjectured relationship between two or more variables expressed in the form of a testable statement. Thus the main hypothesis of this study is proposed as:

$\mathbf{H}_{0}$ : Demographic back ground of the respondents and Locus of control are independent of each other.

\section{LITERATURE REVIEW OF EXSISTING RESEARCH}

This section consists of review of the existing research; the major variables extracted from the previous studies, theoretical framework and the proposed hypotheses.

\section{Existing Research}

Locus of control is the framework of Rotter's (1954) social learning theory of personality, which was defined by Lefcourt (1976: 27) as "as a generalized expectancy for internal as opposed to external control of reinforcements". Early work on the topic of expectancies about control of reinforcement had, as Lefcourt explains, been performed in the 1950s by James \& Phares for his doctoral dissertation supervised by Rotter at Ohio State University. Attempts have been made to trace the genesis of the concept to the work of Alfred Adler, but its immediate background lies in the work of Rotter students William H. James who studied two types of expectancy shifts i.e. Typical expectancy shifts, believing that a success or failure would be followed by a similar outcome; and Atypical expectancy shifts, believing that a success or failure would be followed by a dissimilar outcome.

Work in this field led psychologists to suppose that people who were more likely to display typical expectancy shifts were those who more likely attribute their outcomes to their ability, whereas those who displayed atypical expectancy more likely attribute their outcomes to 
chance Frieri et al., 1980). This means that people could be divided into those who attribute to ability (an internal cause) versus those who attribute to luck (an external cause). However, after 1970, Bernard Weiner pointed out that attributions to ability versus luck also differ in that the former are an attribution to a stable cause, whereas the latter and attribution to unstable cause (Luthan, 2003: 137). Yet a revolutionary work in this field appeared in the journal Psychological Monographs by Rotter (1966). In which, Rotter summarized over ten years of research by himself and his students, much of it previously unpublished. Early history of the concept can be found in Lefcourt (1976), who, early in his treatise on the topic, relates the concept to learned helplessness. Rotter (1975 and 1989) has discussed problems and misconceptions in others' use of the internal versus external control of reinforcement construct.

Rotter (1975) cautioned that internality and externality represent two ends of a continuum, not an either/or typology. Internals tend to attribute outcomes of events to their own control. Externals attribute outcomes of events to external circumstances. For example, University students with a strong internal locus of control may believe that their grades were achieved through their own abilities and efforts, whereas those with a strong external locus of control may believe that their grades are the result of good or bad luck, or to a professor who designs bad tests or grades capriciously; hence, they are less likely to expect that their own efforts will result in success and are therefore less likely to work hard for high grades (Strickland, 1989). It should not be thought however, that internality is linked exclusively with attribution to effort and externality with attribution to luck, as Weiner's work makes clear, obviously this has serious implications for differences between internals and externals in terms of their achievement motivation, suggesting that internal locus is linked with higher levels of $\mathrm{N}$-ach (Furman, 1986). Due to their locating control outside themselves, externals tend to feel that they have less control over their fate. People with an external locus of control tend to be more stressed and prone to clinical depression (Benassi et al., 1988 in: Maltby et al., 2007).

Internals believed, according to findings of the Rotter (1966) and exhibit two essential characteristics i.e. high achievement motivation and low outer-directedness. This was the basis of the locus of control scale proposed by Rotter in 1966. Although this was actually based on Rotter's belief that locus of control is a one-dimensional construct. Since 1970, Rotter's assumption of unidimensionality has been challenged. Levenson, for example, argue that different dimensions of locus of control, such as belief that events in one's life are selfdetermined, are organized by powerful others and are chance-based, must be separated (Benassi et al., 1988). Likewise, Weiner's early work in the 1970s, suggested that, more-or-less orthogonal to the internality-externality dimension, we should also consider differences between those who attribute to stable causes, and those who attribute to unstable causes (Lester, 1992).

The analysis of the above mentioned previous studies points that attributions could be the ability (an internal stable cause), effort (an internal unstable cause), task difficulty (an external stable cause) or luck (an external, unstable cause). Such at least were how the early Weiner saw these four causes, although he has been challenged as to whether people do see luck, for example, as an external cause, whether ability is always perceived as stable and whether effort is always seen as changing. Indeed, in more recent studies for example, Weiner (1980: 801) used different terms for these four causes - such as "objective task characteristics" in place of task difficulty and "chance" in place of luck (Gary, 2006: 77-78). 
It is also notable that how psychologists since Weiner (1980: 801) have distinguished between stable effort and unstable effort - knowing that, in some circumstances, effort could be seen as a stable cause, especially given the presence of certain words such as "industrious" in the English language (Terrence, 1982: 572).

An individual's locus of control can greatly impact work and life. Someone with an internal locus of control would see challenges as opportunities for learning and professional growth. In contrast, others with an external locus of control would ignore these challenges due to their sense that learning will not have an impact on them (Norvilitis et al., 2003). Findings of a study by Judge et al. (1998) advocates that locus of control is highly correlated with self efficacy. They define self-efficacy as an estimate of one's capabilities to mobilize the motivation, cognitive resources, and courses of action needed to exercise general control. According to Lefcourt (198); Phares (1976); Stickland (1977 and 1989) the locus of control has shown a host of relationships to such things as mastery of the environment, achievement, personal health care competence, exercise of interpersonal influence, social activism, helping behavior, and adjustment control over events in one's life. Based on these research findings one can safely assume that persons different in locus of control will differ in their achievement orientation, self-confidence, self-esteem, perceptions of other people and actual performance (Babladelis, 1984). According to researchers like Herbert (1981) belief and behavior differences helpful in understanding the attributes of locus of a person.

\section{Belief Differences}

It has been found that internals believe that they can affect events and outcomes that they can make the future conform to their wishes by appropriate actions while the external, on the other hand, feel powerless and unable to influence events no matter what they do Herbert, 1981). Instead, they believe control over their destinies lies with some outside agency. And this outside source may be fate, luck, chance, or other powerful people. The critical difference between internals and externals is whether or not they feel they can affect outcomes through their own efforts. A study of Johns (1996) elucidates the belief construct with locus of control by giving the following comparison based on Laurie \& Stan, who are management trainees in large banks. However, they have rather different expectations regarding their futures. Laurie has just enrolled in an evening Master of Business Administration program in a nearby university. Although some of her MBA courses are not immediately applicable to her job, Laurie feels that she must be prepared for greater responsibility as she moves up in a bank hierarchy. Laurie is convinced that she will achieve promotions because she studies hard, works hard, and does her job properly. She feels that an individual makes her own way in the world and that she can control her own destiny. She is certain that she can someday be the president of the bank if she really wants to do so. Her personal motto is that I can do it. Stan, on the other hand, sees no use in pursuing additional education beyond his bachelors' degree. According to him, such activities just don't pay off. People who get promoted are just plain lucky or have some special connections and further nothing to do with in .Stan feels that it is impossible to predict his own future but knows that the world is pretty unfair.

The above mentioned assumed story of Laurie and Stan differ on a personality dimension (locus of control). This variable refers to individuals "beliefs" about the location of the factors that control their behavior. At one end of the continuum are high internals (like Laurie) who believe 
that the opportunity to control their own behavior rests within themselves. At the other end of the continuum are high externals (like Stan), who believes that external forcer determine their behavior. Rotter (1966) commented not surprisingly compared with internals, externals see the world as unpredictable, chance place in which luck, fate or powerful people control their destinies.

McComb \& Marzano (1991) suggest that what underlies the internal locus of control is the concept of "self as agent". This means that our thoughts control our actions and that when we realize this function of thinking we can positively affect our beliefs, motivation and academic performance. The self as agent can consciously or unconsciously direct, select, and regulate the use of all knowledge structures and intellectual processes in support of personal goals, intensions and choices (Locke, 1969). McCombs asserts that "the degree to which one chooses to be self-determining is a function of one's realizations of the source of agency and personal control. In other words, we can say to ourselves, I choose to direct my thoughts and energies toward accomplishment. I choose not to be daunted by my anxieties or feelings of inadequacy. Zimbardo (1985) views that, locus of control orientation is a belief about whether the outcomes of our actions are contingent on what we do (internal control orientation) or on events outside our personal control (external control orientation).

\section{Behavior Differences}

We expect that internals and externals behave differently, because their belief of cause and effect differ. Herbert (1981: 35-59) remarked that, one who expects no results to be attributable to his attempts to do a job, for example, would be likely to spend a great deal of working hard. One who believes that what happens is determined by what he does is likely to work hard for desired outcomes. Similarly, internals should prefer jobs or situations (such as games) in which skill matters and should dislike jobs or situations in which luck or chance (not skill) determines how well one does. Lefcourt (1982) while discussing locus of control remarked that with the locus of control construct, we are dealing with a person as he viewed himself in conjunction with the things that befall him, and the meaning that he makes of those interactions between his self and his experience. While Wilson (1999) viewed it as a person's perception of the source of his fate is termed locus of control. Likewise, Pervin (1989) viewed that, individuals may maintain belief about their ability to influence or control events in their lives e.g. locus of control. Carrel \& Heavrin (1997) shared similar view and commented that locus of control determines the degree to which an individual believes that his behavior influences what happens to him.

Norvilitis ET AL. (2003) and Mitchell (1982) while examining the power bases and behaviors used by internals and external managers, find a fairly consistent picture. The internal tends to use more considerate behavior and relies on expertise, rewards, and attractiveness as sources of influence whereas, externals emphasize more coercive power bases and uses more structuring behaviors (Pervin, 1989: 452). This trait may be of potentially importance for predicting individual's effectiveness in the more open and flexible organizational setting that is being forecast for the future.

The implies that the relationship of an individual to external forces is summarized by the nature of the psychological defenses of the personality, and through aggressive, withdrawal, or compromise activities the self-concept is protected, where four motives serve as direct 
personality extension and as consistent behavior patterns, including achievement, power, affiliation and social manipulation.

\section{List of Extracted Variables/ Working Concepts}

1. Belief: According to Wilson (1999) beliefs are the understandings of how objects and ideas relate to each other.

2. Experience: Hughes et al. (2003) defined experience that involves three different processes i.e. action, observation, and reflection. If a person acts but does not observe the consequences of his actions or reflect on their significance and meaning, then it make little sense to say he has learned from an experience.

3. Influence: Hughes et al. (2006) comment that influence can be defined as the change in a target agent's attitudes, values, beliefs, or behavior as the result of influence tactics. Influence tactics refer to one person's actual behaviors designed to change another person's attitude, beliefs, values, or behavior.

4. Ability: According to George \& Jones (1996) \& Herbert (1981: 254) ability is the mental or physical capacity to do something.

\section{Theoretical Framework of the Study}

Theoretical model/framework is shows the logical relationship, cause and effect of dependent and independent variables, wherefrom hypotheses stems, below is the schematic diagram of the theoretical framework of this study.

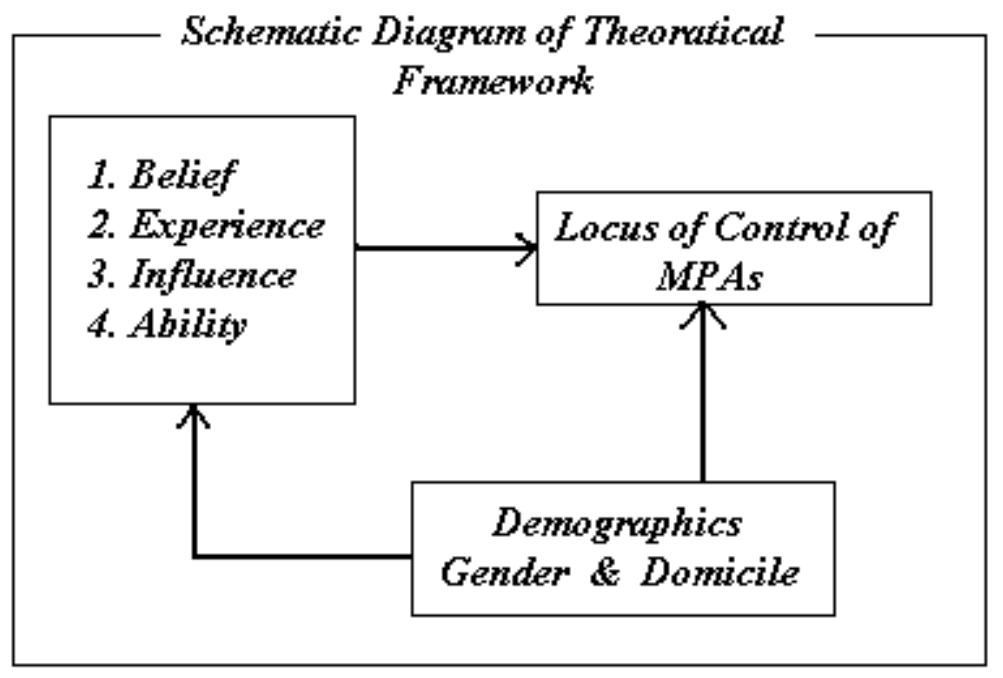

\section{List of Sub Hypotheses}

Since we have 4 research variables and two demographics attributes therefore to check their impacts on the responses we have proposed 8 sub-hypothesis, listed below:

Hypotheses

1 Gender doesn't changes the response on all variables.

2 Domicile doesn't bring variation in the responses of students.
Code

$\mathrm{H}_{1}-\mathrm{H}_{4}$

$\mathrm{H}_{5}-\mathrm{H}_{8}$ 


\section{RESEARCH METHODOLOGY}

This section focus on the methodology of the study, in which the approach, population, sampling, data analysis tools used in the study are presented.

Survey approach with structured questionnaires (extracted from literature review) has been used for the study, which is most frequently used in the social sciences (Babbie, 1993). It enables the researcher to collect every kind of data to answer every question about the topic (Yin, 1994). The students of Department of Public Administration were taken into consideration as a population of the study, so the researcher selected a sample of 30 respondents through convenience sampling technique.

Both secondary and primary data was collected from the existing studies and through administration of structured questionnaires. The variables and attributes extracted from the literature were arranged into a questionnaire. With the help of SPSS 16, both descriptive and inferential analyses were done.

\subsection{OPERATIONALIZATION OF THE CONCEPTS:}

\begin{tabular}{|c|c|c|c|}
\hline Variable & Attribute & Code & Questions \\
\hline Belief & $\begin{array}{l}\text { Mistakes, Bad luck, Efforts, } \\
\text { Links, Interpersonal Skills, and } \\
\text { Fate }\end{array}$ & V1 & Q1, Q2, Q3, Q4, Q5, Q6. \\
\hline Experience & $\begin{array}{ll}\begin{array}{l}\text { Experience, } \\
\text { Dedication, Links, } \\
\text { efforts, Chance }\end{array} & \text { Personal } \\
\end{array}$ & V2 & Q7, Q8, Q9, Q10, Q11, Q12. \\
\hline Influence & $\begin{array}{l}\text { People's participation in politics, } \\
\text { Force, Self confidence, Others } \\
\text { influence, } \quad \text { Participative } \\
\text { leadership, Directive leader ship }\end{array}$ & V3 & $\begin{array}{l}\text { Q13, Q14, Q15, Q16, Q17, } \\
\text { Q18. }\end{array}$ \\
\hline Ability & $\begin{array}{l}\text { Effort, despair, Performance } \\
\text { based evaluation, Biased } \\
\text { teachers, Ability, Luck }\end{array}$ & V4 & $\begin{array}{l}\text { Q19, Q20, Q21, Q22, Q23, } \\
\text { Q24 }\end{array}$ \\
\hline
\end{tabular}

\section{FINDINGS OF THE STUDY}

This part of the article highlights the major results and findings of the study including descriptive and inferential analysis.

\section{a. Demographic profile of respondents:}

1. Gender wise breakdown of the subject sample:

\begin{tabular}{|l|l|l|}
\hline Gender & Frequency & \%age \\
\hline Male & 16 & 53.33 \\
\hline Female & 14 & 46.66 \\
\hline Total & 30 & 100 \\
\hline
\end{tabular}

2. Domicile wise breakdown of the respondents: 


\section{Hypotheses Testing}

\begin{tabular}{|l|l|l|}
\hline Domicile & Frequency & \%age \\
\hline Local & 16 & 53.33 \\
\hline Non-local & 14 & 46.66 \\
\hline Total & 30 & 100 \\
\hline
\end{tabular}

T-test for two independent samples (Glassnapp, 1985: 363) was computed to test the significance of differences between the means of variables for both gender and domicile. One main hypothesis and eight sub hypotheses were proposed. Below are the results and analyses: $\mathbf{H}_{\mathbf{1}}$ : Gender and belief are independent of each other.

\begin{tabular}{|l|l|l|l|l|}
\hline Variable & Degree of freedom & t-value & Table value & Result \\
\hline Belief & 28 & -0.86 & 2.048 & $\mathrm{H}_{1}$ accepted \\
\hline
\end{tabular}

\section{Analysis}

T-test comparing responses of males with the females of MPA students, indicates that there is significant difference in the responses of the male and female for Belief. With 28 degree of freedom, the calculated t-value -0.86 is less than the table value 2.048 , hence $\mathrm{H}_{0}$ is accepted. $\mathbf{H}_{\mathbf{2}}$ : Gender and experience are independent of each other.

\section{Analysis}

\begin{tabular}{|l|l|l|l|l|}
\hline Variable & Degree of freedom & t-value & Table value & Result \\
\hline Experience & 28 & 0.46 & 2.048 & $\mathrm{H}_{2}$ accepted \\
\hline
\end{tabular}

After applying T-test, we checked that is there any significant difference between the gender and experience. Using the level of significance of 0.05 , the tabulated value of t-test for 28 degree of freedom is 2.048 , whereas calculated value is 0.46 . Since the calculated value is less than the tabulated value. Hence $\mathrm{H}_{0}$ is accepted.

$\mathbf{H}_{\mathbf{3}}$ : Gender and Influence are independent of each other.

\begin{tabular}{|l|l|l|l|l|}
\hline Variable & Degree of freedom & t-value & Table value & Result \\
\hline Influence & 28 & 2.076 & 2.048 & $\mathrm{H}_{3}$ rejected, as t-cal is greater than t-tab. \\
\hline
\end{tabular}

\section{Analysis}

T-test comparing responses of gender, indicates that difference between influence and gender is significant. As the calculated value is greater than the tabulated value, thus the null hypothesis $\left(\mathrm{H}_{0}\right)$ is rejected.

$\mathbf{H}_{4}$ : Gender and ability are independent of each other.

\section{Analysis}

\begin{tabular}{|l|l|l|l|l|}
\hline Variable & Degree of freedom & t-value & Table value & Result \\
\hline Ability & 28 & -1.176 & 2.048 & $\mathrm{H}_{4}$ accepted \\
\hline
\end{tabular}

After applying T-test, the results show that there is significant difference between the gender and ability; with (0.05) level of significance, tabulated value of t-test for 28 degree of freedom is 2.048, and calculated value is -1.176 . Since the calculated value is less than the tabulated value, so $\mathrm{H}_{0}$ is accepted.

$\mathbf{H}_{5}$ : Domicile and belief are independent of each other. 


\section{Analysis}

\begin{tabular}{|l|l|l|l|l|}
\hline Variable & Degree of freedom & t-value & Table value & Result \\
\hline Belief & 28 & -0.478 & 2.048 & $\mathrm{H}_{5}$ accepted \\
\hline
\end{tabular}

T-test comparing responses of locals with the Non-locals of MPA students, indicates that there is a significant difference between the domicile and belief. As at 28 degree of freedom, the calculated t-value -0.478 is less than the table value 2.048 , hence hypothesis $\mathrm{H}_{5}$ is accepted.

$\mathbf{H}_{6}$ : Domicile and experience are independent of each other.

\section{Analysis}

\begin{tabular}{|l|l|l|l|l|}
\hline Variable & Degree of freedom & t-value & Table value & Result \\
\hline Experience & 28 & 1.093 & 2.048 & $\mathrm{H}_{6}$ accepted \\
\hline
\end{tabular}

To check the mean difference, again t-test was used. Group variables was domicile and research variable was experience, the researcher used 0.05 level of significance to test the hypothesis, results indicate that tabulated value of t-test with 28 degree of freedom is 2.048 is less than the tabulated value, thus, $\mathrm{H}_{0}$ is accepted.

$\mathbf{H}_{\mathbf{7}}$ : Domicile and influence are independent of each other.

\section{Analysis}

\begin{tabular}{|l|l|l|l|l|}
\hline Variable & Degree of freedom & t-value & Table value & Result \\
\hline Influence & 28 & -0.93 & 2.048 & $\mathrm{H}_{7}$ accepted \\
\hline
\end{tabular}

T-test comparing results of domicile (locals, non-locals of MPA students) indicates that there is a significant difference between domicile and influence. As at 28 degree of freedom, the calculated t-value -0.93 is less than the table value 2.048 , hence $\mathrm{H}_{0}$ is accepted.

$\mathbf{H}_{\mathbf{8}}$ : Domicile and ability are independent of each other.

\begin{tabular}{|l|l|l|l|l|}
\hline Variable & Degree of freedom & t-value & Table value & Result \\
\hline Ability & 28 & -0.34 & 2.048 & $\mathrm{H}_{8}$ accepted \\
\hline
\end{tabular}

\section{Analysis}

T-test was used to compare the responses of locals with the Non-locals of MPA students, the results indicate that there is a significant difference between domicile and ability. As at 28 degree of freedom, the calculated t-value -0.34 is less than the table value 2.048 , so our $\mathrm{H}_{0}$ is substantiated and accepted.

\section{DISCUSSION}

The analysis of the data collected from relevant literature and results of the study indicates insignificant differences between the gender and domicile about the four variables. However, significant difference between gender and influence wad found. This section intends to explore the possible explanation behind the significant difference between gender and influence towards the research topic.

\section{Influence \& Locus of Control}

Wilson (1999) while defining influence commented that it's the way through which individual translate power bases into specific actions. Evidence from the literature (Jennifr et al., 1996: 46) 
strongly suggests that Influence is an important predictor for development of locus of control in individuals .As according to Lefcourt (1982) when a person believes that he is the responsible agent or source of his own life's fortunes, he will resist influence and attempts to bypass his own sense of moral justice, and only respond to those appeals that address themselves to his own beliefs and values (Michael ET AL., 1997: 101). In effect the internal will not- surrender of a sense of responsibility when succumbs along with others to manipulation (Judge, 1998).

This argument indicates that internals do not take influential attempts whether those are from family, powerful persons /higher authorities or environment as they consider themselves as pawn of their fate, while on the other hand external take much influence from those aforementioned forces to develop their locus of control. The finding from the present study shows that the difference between gender and influence is significant to those of other variables which show sex difference changes responses towards influential attempts.

\section{Influence of Familial Origins}

The development of locus of control is associated with family style and resources, cultural stability and experience with efforts leading to reward. Several internals have grown up with families that model the typical internal beliefs, such families emphasize on efforts, education, responsibility and thinking. Schultz \& Schultz (2005) also point that children who develop an internal locus tend to come from families where parents have been supportive and consistent in self-discipline. However, there is some ambiguity, whether parental locus of control influences a children's locus of control or not? At least one study (Parke, 1990) has found that children are more likely to attribute their successes and failures to unknown causes if their parents have an external locus of control.

\section{Influence of Peer Groups}

Parke (1990) in his study observed that when children move out from the family to child-care centers, school, and the community at large, they begin to form attachments, and friendships which might emerge during their play (McCombs \& Marzano, 1991: 6-7). These relationships influence behavior, even infants and toddlers are observed reacting to other infants by touching them, crying when others cry, and later by offering nurturance or comfort (Joan Wilson, 1999: 332). While in their third year of age, early friendships begin to form and children's peers begin, which have more lasting influence (Rotter, 1954: 293). Similarly, individual's in different organizations and work places develop locus of control under the influence of prevailing environment, more influential managers and administrators etc.

\section{Gender\& Influence}

It has been suggested by several research studies that masculine characteristics have broader adaptive significance for the individuals than to feminine characteristics (see for example, Jones et al., 1978; Orlofsky \& Stake, 1981; Whitley, 1984). Masculine characteristics have been viewed as a source of psychological strengths in both the interpersonal and intrapersonal domains, operating concurrently with achievements strivings, feelings of self-confidence, and social dominance (Glasnapp \& Poggio, 1985: 168, 363). In contrast, the primary contributions of feminine characteristics are centered more narrowly in affective and interpersonal spheres (Walpole, 1974: 866). 
Since masculine-instrumental traits and behaviors are valued highly in this society, individuals who manifest these characteristics receives greater recognition and approval, and thus may be better adjusted, than individuals who do not exhibit these characteristics. This shows that individuals with masculine characteristics are more dominant on outside forces then that of feminine.

\section{CONCLUSIONS \& SUGGESTIONS}

\section{Conclusions}

This research was conducted to measure the locus of control tendencies among students of Master of Public Administration Gomal University DIKhan, Pakistan. The quantitative data on different variables was collected such as Belief, experience, influence and ability. The study found a lack of significant differences between the research variables and demographic back ground of the respondents. The study reveals that there is no significant difference between the responses of males and females about belief, likewise, no difference of opinion between males and females about the experience was found. Similarly, this study also points that the difference between the opinion of males and females about influence is significant. Moreover, results of the t-test highlight that the difference between responses of gender on the ability is insignificant. This research also explains that there is no significant difference between views of locals and non-locals about the belief. As evident for the results of t-test, no difference between the responses of domicile and the experience was there, likewise, no significant difference between the responses of locals and non-locals with influence was found. The finding of the study also reveals that there was no difference between the responses of domicile and the ability. Keeping in view the results summarized above, it could be safely concluded that it appear to underline the importance of gender characteristics with their adjustive capacities to respond influence and belief in his own ability to control life's event.

\section{Suggestions}

In this study, t-test was used to measure the impacts of the demographic variables upon the research variables. In this connection eight hypotheses were developed. The results show that there are no significant differences between the responses of males \& females, locals \& nonlocals about the belief, experience, influence and ability. The results of the research highlight that one demographic group (gender) have different perception about the influence on locus of control. Based on the findings, the study suggest that generally, the development of locus of control stems from family, culture, and environment so there is a need to make the individuals perceive positive things out of them which would resultantly make them a moderate internal. Therefore, individuals must be given equal opportunities in every filed of work without any sexual discrimination. Likewise, individuals must be given a chance to set goals for themselves, by working towards those goals and achieving them, they are actually controlling what happens in their lives. As they will do that they will find that their self-confidence is quickly building. Moreover, individuals must develop their decision making and problem solving skills so that they can feel more confident, and in control of what happens. With these tools, they will find that they can understand and navigate through situations/ Influences that would otherwise damage them. 


\section{Reference}

1. Babladelis, M.E. (1984). Locus of Control: A personality dimension, CBS college Publishing, New York.

2. Barbara, E. (1985). Personality theories: An introduction, $2^{\text {nd }}$ Ed., Houghton-Mifflin Company.

3. Bell, N., \& Staw, B. (1989). People as sculptors versus sculpture: The role of personality and personal control in organizations, In: Ott, J. (Ed.) Classic readings in organizational behavior, Harcourt Brace \& Company, Florida.

4. Bush, J. (1988). Job satisfaction, powerlessness, and locus of control, Western Journal of Nursing Research, 10(6): 718-731.

5. Chung, J., \& Reigeleuth, C.M. (1992). Instructional prescriptions for learner control, Educational Technology, 2(4): 14-20.

6. Frieri, F., Bartal, D., \& Carol, D. (1980). Attribution theory: Application to social problems, (eds.), San Francisco Co: Jossey-Bass.

7. Furman, R.A. (1986). Emotions and Behavior Monograph, Mono No: 5, pp. 21-34.

8. Gary Johns (2006). Organizational behavior, Harper Collins Publishers, New York.

9. Glasnapp, D. \& Poggio, J. (1985). Essentials of statistical analysis for the behavioral sciences, Public by Charles, Merrill Publishing Co.

10. Herbert. M. Lefcourt, (1982). Locus of control: Current trends in theory and research, $2^{\text {nd }}$ Ed., Lawrence Erlbaum Associates, Publishers, New Jersey.

11. Jennifr, M., George, Gareth R. Jones, (1996). Understanding and managing organizational behavior, Addison-Wesley Publishing Company.

12. Joan Wilson (1999). Fundamental of organizational behavior, $3^{\text {rd }}$ Ed., Pergmon Press New York.

13. Judge. T., Locke, E., Durham, C., \& Kluger, A. (1998). Dispositional effect on job satisfactions and life satisfaction: The role of core evaluations, Journal of Applied Psychology, 83: 17-34.

14. Pervin, L. A. (1989). Personality theory and research, $5^{\text {th }}$ Ed., John Wiley \& Sons Inc. New York.

15. Lester, D. (1992). Co-operative/competitive strategies and locus of control, Psychological Reports, 171 (2): 23-38.

16. Locke, E. (1969). What is job satisfaction, Organizational Behavior and Human Performance, 4(1): 309-336.

17. Luthans, Fred. (2003). Organizational Behavior, $7^{\text {th }}$ Ed. McGraw-Hill Inc., New York.

18. Maltby, J., Day, L., \& Macaskill, A. (2007). Personality, individual differences and intelligence, Pearson Prentice-Hall, Harlow, ISBN 0-13-12976-0.

19. McCombs, B. \& Marzano, R. (1991). What is the role of the will component? In: Weinstein, C.E., \& McCombs, B.L. (Eds.), Strategic learning: Skill .will and self-regulation. Lawrrence Erlbaum Associates, Hillsdale, NJ.

20. Michael, R., Carrel, D.F., \& Jennings, C. Heavrin (1997). Fundamentals of organizational behavior, International Edition, Prentice Hall International, New Jersey.

21. Nielson, L. (1982). How to motivate adolescents, Englewood, NJ: Prentice-Hall Inc. New Jersey. 
22. Norvilitis, J.M., Szablicki, P.B., \& Wilson, S.D. (2003). Factors influencing levels of creditcard debt in college students, Journal of Applied Social Psychology, 33(5): 935-947.

23. Phares, E.J. (1976). Locus of control in personality, General Learning Press, Norristown, NJ.

24. Phillip Zimbardo (1985) Role of locus of control in developing human behavior, Psychological Review, 2(1): 275.

25. Phillips, A.S., \& Bedeian, A.G. (1994). Leader-followers exchange quality: The role of personal and interpersonal attribute, Academy of Management Journal, 2(1): 990-1001; and Behavior in organizations as a function of employees: Locus of control, Spector, 2(3): 482-497.

26. Richard, L. Hughes, Ginnett, R.C. \& Curphy, G.J. (2006). Leadership- enhancing the lessons of experience, $5^{\text {th }} \mathrm{Ed}$. Tata McGraw-Hill, New Delhi.

27. Rotter, J.B. (1954). Social learning and clinical psychology, Prentice-Hall, Englewood Cliffs, NJ.

28. Rotter, J.B. (1966). Generalized expectancies for internal versus external control of reenforcement, Psychological Monograph, 80(1): 609.

29. Schultz, D.P. \& Schultz, S.E. (2005). Theories of personality, $8^{\text {th }}$ Ed. Wadsworth Thomson, ISBN: 0-534-62403-2.

30. Sekaran Uma (1999). Research methods for business, $4^{\text {th }}$ Ed., Weily \& Weily, UK.

31. Strickland, B.R. (1989). Internal-External control expectancies: From contingency to creativity, American Psychologist, 44: pp. 1-12.

32. Terrence, R. Mitchell (1982). People in organizations: An introduction to organizational behavior, $2^{\text {nd }}$ Ed. Mc-Graw Hill Company, New York.

33. Herbert, T.T. (1981). Dimensions of organizational behavior, $2^{\text {nd }}$ Ed., Macmillan Publishing Co. New York.

34. Walpole, R. (1974). Introduction to statistics, McMillan Publishing Co, Inc. $3^{\text {rd }}$ Avenue, New York.

35. Weiner, B. (1980). Human motivation. $2^{\text {nd }}$ International Ed., Holt, Rinehart and Winston, New York. 